\title{
Replacement of strain NCTC 4175, since 1963 the neotype strain of Proteus vulgaris, with strain ATCC 29905 - Opinion 70
}

\author{
Judicial Commission of the International Committee on Systematic \\ Bacteriology
}

\section{The Judicial Commission decided that strain NCTC 4175, used as the neotype strain of Proteus vulgaris since 1963, be replaced by strain ATCC 29905.}

Keywords: Proteus vulgaris, NCTC 4175, ATCC 29905, neotype strain, Judicial Opinion 70

Upon a proposal by Buchanan et al. (1959), strain NCTC 4175 had been designated as the neotype strain of Proteus vulgaris in Opinion 23 (Buchanan et al., 1963) together with neotype strains of other species of the Enterobacteriaceae.

The present decision of the Judicial Commission is based upon the respective Request for an Opinion by Brenner et al. (1995), especially upon the following arguments:

(i) Retaining NCTC 4175 as the neotype strain violates Principle 1 (Lapage et al., 1992) in that it causes nomenclatural instability and would result in a name that may cause error or confusion.

(ii) Replacing NCTC 4175 is in accordance with Principle 9 (Lapage et al., 1992) in that additional taxonomic studies have indicated that the original designation was in error, because a strain that is genomically different from the vast majority of strains assigned to the species was designated the neotype strain.

(iii) In violation of Rule 18c (Lapage et al., 1992), neither a description nor a reference to an effectively published description was given when NCTC 4175 was proposed as the neotype strain.

(iv) NCTC 4175 became unsuitable as the neotype strain when it was determined that genomically this strain differs from the vast majority of strains assigned to the species.

The new neotype strain ATCC 29905 is well characterized (Lautrop, 1974), has been used as the DNA relatedness reference strain since 1978 (Brenner et al.,
1978) and has been available from the American Type Culture Collection since 1980.

\section{References}

Brenner, D. J., Farmer, J. J., III, Fanning, G. R., Steigerwalt, A. G., Klykken, P., Wathen, H. G., Hickman F. W. \& Ewing, W. H. (1978). Deoxyribonucleic acid relatedness of Proteus and Providencia species. Int J Syst Bacteriol 28, 269-282.

Brenner, D. J., Hickman-Brenner, F. W., Holmes, B., Hawkey, P. M., Penner, J. L., Grimont, P. A. D. \& O'Hara, C. M. (1995). Replacement of NCTC 4175, the current type strain of Proteus vulgaris, with ATCC 29905. Request for an Opinion. Int J Syst Bacteriol 45, 870-871.

Buchanan, R. E., Cowan, S. T. \& Clark, W. A. (editors) (1959). Designation of neotype cultures of the type species of certain genera of the family Enterobacteriaceae: Salmonella, Shigella, Arizona, Escherichia, Citrobacter, and Proteus. Int Bull Bacteriol Nomencl Taxon 9, 105-107.

Buchanan, R. E., Seeliger, H. P. R. \& Clark, W. A. (editors) (1963). Opinion 26. Designation of neotype strains (cultures) of type species of the bacterial genera Salmonella, Shigella, Arizona, Escherichia, Citrobacter, and Proteus of the family Enterobacteriaceae. Int Bull Bacteriol Nomencl Taxon 13, 35-36.

Lapage, S. P., Sneath, P. H. A., Lessel, E. F., Skerman, V. D. B., Seeliger, H. P. R. \& Clark, W. A. (editors) (1992). International Code of Nomenclature of Bacteria (1990 Revision). Bacteriological Code. Washington, DC: American Society for Microbiology.

Lautrop, H. (1974). Genus X. Proteus, pp. 327-330. In Bergey's Manual of Determinative Bacteriology, 8th edn. Edited by R. E. Buchanan \& N. E. Gibbons. Baltimore: Williams \& Wilkins. 